\title{
Proqram təminatının testləşdirilməsi üçün sınaq texnologiyalarının təhlili
}

\author{
Tamilla Bayramova ${ }^{1}$, Nəzakət Məlikova ${ }^{2}$ \\ ${ }^{1,2}$ AMEA İnformasiya Texnologiyaları İnstitutu, Bakı, Azərbaycan \\ ${ }^{1}$ toma_b66@mail.ru, ${ }^{2}$ naranara_68@mail.ru
}

\begin{abstract}
Xülasə- Məqalədə proqram təminatının sınağı prosesində istifadə olunan terminlər, sınağının keçirilməsi üçün istifadə olunan vasitələr və müxtəlif metodlar haqqında məlumat verilmişdir. Burada sınağın prinsipləri təhlil edilmiş və sınaq prosesində onların nəzərə alınmasının vacibliyi vurğulanmışdır.
\end{abstract}

Açar sözlor- proqram mühondisliyi; test prinsiplori; test-keys; testin planı; testin dizaynı

\section{GİISS}

İnformasiya Kommunikasiya Texnologiyaları (İKT) məhsulları və xidmətləri iqtisadi cəhətdən inkişaf etmiş və inkişaf etməkdə olan ölkələrdə kommersiya, sənaye və məişət sahələrində geniş yayılmışdır. Həyatın bütün sahələrində kompüterləşmiş qurğulardan istifadə edilməsi nəticəsində bütün dünya proqram sistemləri və onlarla əlaqəli xidmətlərin təsiri altına düşmüşdür.

İKT məhsul və xidmətlərinin çeşidləri armış və getdikcə daha da genişlənir (ürək ritmi sistemləri, trafikin idarə edilməsi sistemləri, informasiya sistemləri, bulud xidmətləri, əşyaların interneti və s.). İstifadəçinin maraqlarını qorumaq üçün proqram təminatının (PT) xətaları və imtinası nəticəsində yarana biləcək bütün növ riskləri minimallaşdırmaq lazımdır. $\mathrm{Bu}$ işdə proqram mühəndislərinin üzərinə daha böyük vəzifə düşür. PT-ni işləyənlər və sistem mühəndisləri etibarlı və təhlükəsiz sistemlər yaratmaqla biznes, sənaye və bütün cəmiyyət üçün etibarlı xidmətin göstərilməsini təmin etmolidirlər.

Müasir proqram sistemlərinin düzgün işləməsinə və etibarlılığına təminat vermək üçün PT-nin həyat dövrünün müxtəlif mərhələlərində verifikasiya və validasiya metodlarından istifadə edərək onda olan səhvlər ardıcıl şəkildə aradan qaldirılır.

Sınaq verifikasiyanın dinamik analiz metodlarına aiddir, o PT-nin bütün həyat dövründə müxtəlif səviyyələrdə aparılır. Müvafiq olaraq sınaq da müxtəlif mərhələlərlə həyata keçirilir [1].

\section{PROQRAM TӘMINATININ SINAĞI}

PT-nin sinağ1 (software testing) keyfiyyətə nəzarət texnikalarından biri olub proqramın gözlənilən və real işi arasındakı uyğunluğu müəyyən edir və seçilmiş testlər toplusu əsasında müəyyən qaydada həyata keçirilir. Burada sınaqdan keçirilən sistemin və ya komponentin layihə həllərinə, tələblərə, layihənin işlənildiyi ümumi məqsədlərə uyğunluğu yoxlanılır. Sinağın keçirildiyi hallara test vəziyyəti (test situations, test purposes), bu vəziyyətlərin yoxlanılmasını təsvir edən prosedurlara isə test deyilir [2].

Şəkil 1-də sınaq prosesinin ümumi sxemi verilmişdir.

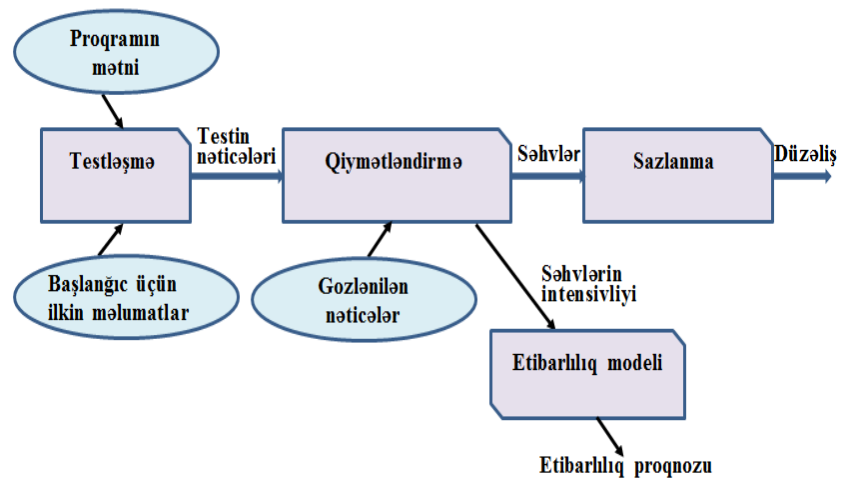

Şəkil 1. Sınaq prosesinin ümumi sxemi bilər:

PT-nin sınağı aşağıda göstərilən məqsədlərlə həyata keçirilə

- Sinaq üçün nəzərdə tutulan vasitələrin istənilən halda düzgün işləyəcəyi ehtimalını artırmaq;

- Sinaq üçün nəzərdə tutulan vasitələrin istənilən halda əvvəlcədən göstərilmiş tələblərə uyğun olacağ 1 ehtimalını artırmaq;

- $\quad$ PT-nin hal-hazırki vəziyyəti haqda aktual informasiya vermək.

PT-nin sınağı zamanı test keys, test planı, test dizayn, çeklist və səhvlər haqqında hesabat hazırlanır.

Test-keys sınaqdan keçirilən funksiyanın reallaşdırılmasını yoxlamaq üçün tələb olunan xüsusi şərtləri və parametrləri təsvir edir. Hər bir test keys 3 hissədən ibarət olmalıdır:

- Illkin şərtlor (PreConditions) əsas sınağın aparılması məqsədilə sistemi müəyyən vəziyyətə gətirmək üçün lazım olan şərtlərin və fəaliyyət növlərinin siyahısıdır; 
- Test keysin tosviri (Test Case Description) sistemin qoyulan tələbləri yerinə yetirdiyinə əmin olmaq üçün onun bir vəziyyətdən digərinə keçirən fəaliyyət növlərinin siyahısıdır;

- Son şartlar (Post Conditions) Sistemi sinaqdan əvvəlki başlanğıc vəziyyətə qaytarmaq üçün lazım olan işlərin siyahısıdır.

Test keyslər gözlənilən nəticədən asılı olaraq müsbət və mənfi test keyslərə bölünür:

- Müsbət test- keys yalnız düzgün verilənlərdən istifadə etməklə proqramın tələb olunan funksiyanı düzgün yerinə yetirməsini yoxlayır:

- Monfi test- keys həm düzgün, həm də yanlış verilənlərlə (ən azı 1 yanlış parametr) işləyir və proqramda baş verəcək xüsusi halları yoxlayır.

Testin planı sınağa aid bütün işlərin (obyektin təsvir edilməsi, strategiyalar, başlama və sona çatma meyarlarından başlayaraq iş müddətində lazım olan avadanlıqlara, xüsusi biliklərə və risklərin qiymətləndirilməsinə qədər) təsvir edilməsi üçün sənəddir.

Testin dizaynı PT-nin sınaq mərhələsindən biridir. Burada əvvəlcədən müəyyən edilmiş keyfiyyət meyarlarına və sınağın məqsədinə uyğun olaraq test keyslər layihələndirilir və yaradılır. Testin dizaynı test analitiki vo test dizayneri tərəfindən həyata keçirilir:

- test analitiki müəyyən edir ki, "Nəyi yoxlamaq lazımdır?";

- test dizayneri müəyyən edir ki, "Necə yoxlamaq lazımdır?".

Çek-list (check list) — nəyin sınaqdan keçiriləcəyini təsvir edən sənəddir. Adətən burada ancaq fəaliyyət növləri göstərilir, gözlənilən nəticələr qeyd edilmir.

Sohvlar haqqında hesabat (Bug Report) - sınaqdan keçirilən obyektin xətalı işləməsinə səbəb olan halları (səbəbləri və gözlənilən nəticələri göstərməklə) özündə əks etdirir [3].

PT-nin sınağının aparılması üçün müxtəlif sınaq metodları işlənilmişdir. Bu metodlar yoxlanılan elementlərin səviyyəsinə və miqyasına və məqsədinə görə sınaq metodlarına bölünür. (şəkil 2).

Qeyri-funksional sinaq metodlarına aid olan təhlükəsizliyin sınağ1 PT-nin müxtəlif hücumlara qarş1 davamlılığını yoxlayır, sistemdə olan mühafizə mexanizmlərinin fəaliyyətinin pozulmasina cəhd edilir [4]. Ogər sinaq zamanı PT bütün təhdidlərə qarşı davamlılı̆̆ını qoruyarsa sınaq çona çatır.

Hal-hazırda mövcud olan sınaq metodları bütün səhvləri aşkar etməyə imkan vermir. PT-nin sınağı və verifikasiyası məsələsini həll etmək üçün müxtəlif yanaşmalar var, lakin bu proseslər yaradıcı proses olduğundan onların həyata keçirilməsi üçün dəqiq qaydalar yoxdur. Sınaq metodları ilə yanaşı bəzi sınaq prinsipləri də mövcuddur. PT-nin son 40 ildə işlənilmə təcrübəsinə əsaslanaraq sinaq prosesinin prinsipləri işlənilmişdir.

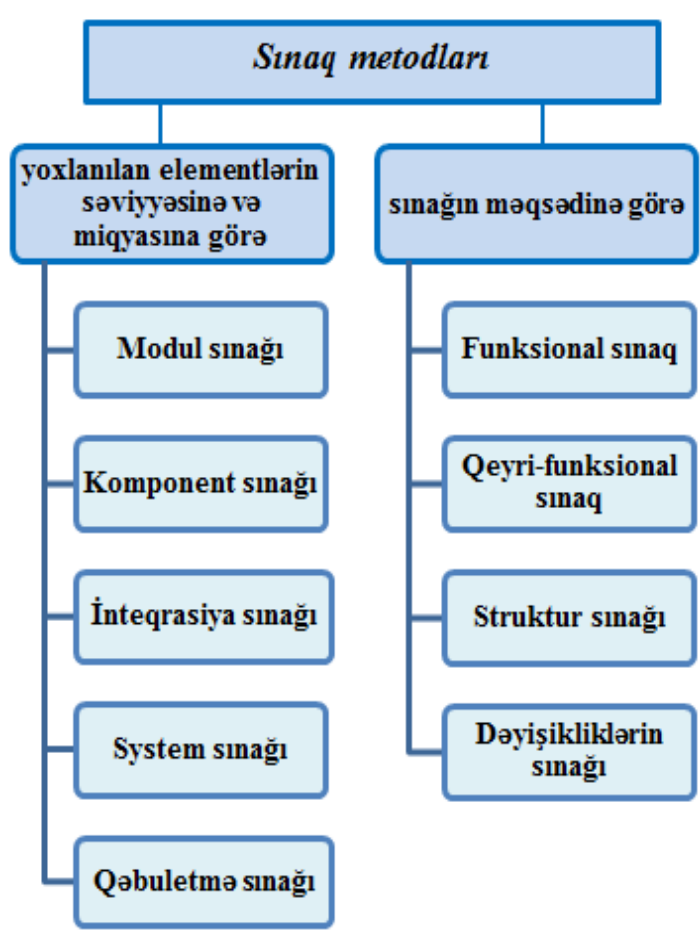

Şəkil 2. PT-nin sınaq metodları

\section{PROQRAM TӘMINATININ SINAĞI PRINSSIPLӘRİ}

Aşağıda PT-nin sınaq prinsipləri verilmişdir [5, 6]:

Prinsip 1: Sınaq prosesinə başmazdan əvvəl gözlənilən nəticə müəyyən edilməlidir.

PT-nin sınağına başlamazdan öncə gözlənilən nəticələr müəyyən edilir. Әgər gözlənilən nəticə öncədən təyin edilməzsə, o zaman inandırıcı görünən amma doğru olmayan nəticəni doğru kimi qəbul etmək təhlükəsi yaranır. Bundan əlavə əgər gözlənilən nəticələr öncədən yazılı şəkildə qeyd edilərsə, o zaman vaxt aparan müzakirələrdən də qaçmaq olar. $\mathrm{Bu}$ prinsipi nəzərdən qaçırdıqda sınaq prosesində coxlu səhvlər ola bilər.

Bu səbəbdən test-keys özündə 2 komponenti saxlamalıdır:

- giriş verilənlərinin təsviri;

- göstərilmiş giriş verilənlərinə müvafiq olan düzgün çıxış verilənlərinin dəqiq təsviri;

Prinsip 2: Proqramçı heç vaxt öz proqramını sınaqdan keçirməməlidir.

$\mathrm{Bu}$ prinsip heç də o demək deyildir ki, proqramçıya öz proqramını test etməyə icazə verilmir. Proqramçıların çoxu öz proqramlarını səmərəli şəkildə sınaqdan keçirə bilmir, çünki fikrini səhvləri aşkar etməyə yönəldə bilmir. Həmkarlar, rəhbərlik, müştəri və ya sahibkarlar tərəfindən cəza qorxusu onun səhvlərdən qaçmasına gətirib çıxarır. Proqramçının 


\section{“Informasiya tohlükosizliyinin aktual multidissiplinar elmi-praktiki problemlori” \\ IV respublika konfransı, 14 dekabr 2018-ci il}

qoyulmuş məsələni və sənədləşməni düzgün başa düşməməsindən irəli gələn proqram səhvləri də ola bilər. Onda o, öz proqramını sınaqdan keçirəndə də bu anlaşılmazlıqdan meydana gələn səhvləri tapa bilməyəcəkdir. Ona görə də sinaq başqa mütəxəssislər tərəfindən daha səmərəli həyata keçirilir.

Prinsip 3: PT-ni işləyən təşkilatlar öz proqramlarını sınaqdan keçirməməlidir.

Təşkilatın və ya onun menecerinin işini PT-ni müəyyən olunmuş vaxt və büdcə vəsaitləri çərçivəsində hazırlamaq qabiliyyəti ilə qiymətləndirirlər. Ona görə ki, bu parametrlər əsasında qiymətləndirmə PT-nin keyfiyyətinin qiymətləndirilməsindən asandır. Bu səbəbdən də PT-ni işləyən təşkilatın səmərəli sınaq proseslərinin keçirilməsində marağ 1 olmur, verilən iş qrafiki və xərclər daxilində sınağın keçirilməsinə çalışırlar.

Prinsip 4: Testlərin nəticələri əsaslı şəkildə dəqiq tədqiq və təhlil edilməlidir.

Bəzi hallarda əvvəlki testin nəticələrində səhvlərin olduğu nəzərdən qaça bilir. Mümkün olduğu qədər səhvləri proqram təminatının yaradılmasının ilkin mərhələlərində aşkar etmək lazımdır. Ogər səhvlər sonrakı mərhələlərdə ortaya çıxarsa yerini müəyyənləşdirmək və aradan qaldırmaq çox çətin olar. Proqramçıların çoxu öz proqramları ilə elə tanışdırlar ki, onlar nəticələrdəki detalları gözdən qaçırırlar. Bəzən bu səhvlər bir hərf səhvindən də irəli gələ bilər.

Prinsip 5: Test-keyslər həm düzgün və gözlənilən giriş verilənləri, həm də xətalı və gözlənilməyən giriş verilənləri üçün tərtib olunmalıdır.

$\mathrm{Bu}$ o deməkdir ki, ekstremal şərtlərdə PT-nin fəaliyyəti təhlil edilməlidir. İstifadəçinin məhsul ilə işləyəcəyi bütün ssenariləri müəyyən etmək mümkün deyil. Bəzi hallarda sınağın xətalı və gözlənilməyən giriş verilənləri ilə aparılması ən ciddi və təhlükəli səhvlərdən vaxtında qaçmağa imkan verir.

Prinsip 6: Bir proqramın tələblərdə göstərilən hansı məsələni icra etmədiyini müəyyənləşdirmək məqsədi ilə aparılan araşdırmalar hələ işin yarısı deməkdir.

Digər yarısı isə proqramın icra etməməli olduğu hansı məsələləri yerinə yetirdiyini aydınlaşdırmaqdan ibarətdir. Ogər proqram icra etməməsi lazım olan işləri də edirsə o da səhv sayilır.

Prinsip 7: Bir dəfə istifadə edilən test-keysləri ancaq bir dəfəlik tətbiq edilən (təkmilləşdirilməyən) proqramlar üçün hazırlamaq olar.

Məsələ ondadır ki, test-keyslərin işlənilməsi üçün vaxt və vəsait lazımdır. Ogər sınaq prosesi bitdikdən sonra onlar itirilərsə PT-nin təkrar sınağı lazım gəldikdə test-keyslər yenidən işlənilməlidir. Bu əlavə iş deməkdir və bəzi hallarda yenidən işlənilmiş test-keyslər PT-də olan səhvləri tapa bilmir. $\mathrm{Bu}$ problem bir çox proqramların sınağı zamanı müxtəlif sistemlərdə meydana gələ bilər.

Prinsip 8: Sınaq prosesinə "səhv tapılmayacaq" fikri ilə başlamaq olmaz.
Layihə menecerlərinin ən çox etdiyi səhvlərdən biridir. Bəzi hallarda sınaq prosesi PT-nin düzgün işlədiyini nümayiş etdirmək məqsədi daşıyır, əslində isə prosesə başlayarkən məqsəd qoyulmalıdır ki, səhvlər tapılacaq. Çünki tamamilə səhvi olmayan PT-ni işləmək mümkün deyildir. Hətta keyfiyyətli sınaq prosesindən sonra belə PT-də səhvlərin olduğu güman edilir, sadəcə olaraq onlar hələ tapılmamışdır.

Prinsip 9: PT-nin müəyyən hissəsində səhvlərin olması ehtimalı bu hissədə tapılan səhvlərin sayına mütənasibdir.

Proqram kodunun müəyyən bir seqmentində səhvlər artıq aşkar edilibsə onların yaxın ətrafında digər səhvlərin tapılma ehtimalı daha yüksəkdir. Məsələn, A və B modulları var və PT-ni sınaqdan keçirən 20 səhv A modulunda və 3 səhv B-də aşkar etmişdir. Bu halda demək olar ki, digər səhvlər də B moduluna nisbətən A modulunda daha çox olacaq. PT-nin keyfiyyətinin təyin edilməsi üçün mövcud olan riyazi modellər moduldakı məlum olan səhvlər əsasında qalan səhvləri hesablamağa imkan verir. Bu ehtimal onu göstərir ki, proqram kodunun hər hansı hissəsində səhvlər digərlərinə nisbətən daha çox tapılırsa bu hissənin sınağını bir qədər çox aparmaq lazımdir.

Prinsip 10: PT-nin sınağı mütəxəssisin yaradıcı və intellektual qabiliyyətlərini nümayiş etdirir.

PT-nin sınağ1 üzrə mütəxəssislərin işi tapılan səhvlərin sayına görə qiymətləndirilir. Sınağı keçirənlər indiyə qədər aşkar edilməyən səhvləri tapmağa imkan verən yaxşı test-keys hazırlamalıdırlar. Belə test-keyslərin tərtib edilməsi PT-nin işlənilmə prosesinə nisbətən daha çox yaradıcı və intellektual qabiliyyət tələb edir.

İstənilən PT-nin sınağı zamanı istifadə ediləcək sınaq metodları ilə yanaşı sınaq prinsiplərinə də diqqət yetirilməsi vacib şərtlərdən biridir.

\section{NӘTİCə}

Yuxarıda göstərilən prinsiplərə əsasən belə bir nəticəyə gəlmək olar ki, PT-nin sınağının müvəffəqiyyətlə aparılması üçün aşağıdakılara diqqət yetirmək lazımdır:

- Səhvləri aşkar etmək ehtimalı yüksək olan test yaxşı hesab olunur;

- Sınağı ən bacarıqlı proqramçılar aparmalıdır;

- Sinaq işlənilən proqramın əsas məsələsi kimi nəzərdən keçirilməlidir;

- Sınağı asanlaşdırmaq üçün proqramı dəyişmək lazım deyil;

- Hər hansı bir başqa fəaliyyət kimi sınaq da məsələnin qoyuluşu ilə başlamalıdır, yoxlanılacaq funksiyalar və gözlənilən nəticələr test-keyslərdə göstərilməlidir.

İnformasiya texnologiyalarının vacibliyinin artması ilə PTdə olan səhvlərin cəmiyyətin həyatında vurduğu ziyanın da qiyməti artır. PT-də olan səhvləri vaxtında aşkar edib düzəltməyə imkan verən sınaq metodları və texnologiyaları ön plana çıxır. Hal-hazırda PT-nin etibarlılığının və 
təhlükəsizliyinin yüksəldilməsi üçün çoxlu sayda sınaq metodları işlənilmişdir. Keyfiyyətli PT -nın olması şirkətin etibarlı fəaliyyətini təmin edir. Elə bu səbəbdən də PT-nin keyfiyyətinin yüksəldilməsi üçün sınaq məsələlərinə xüsusi diqqət yetirilməlidir. Eyni zamanda "Proqram mühəndisliyi" üzrə yüksək ixtisaslı kadrların hazırlanmasında da PT-nin sınaq metodları və vasitələrinin tədrisi böyük əhəmiyyətə malikdir.

\section{ӘDӘBIYYAT}

[1] Verifikation, Validation und Testen von Sicherheitskritischen Systemell, http://pi.informatik.uni-siegen.de/niere/lehre/SS04/ SeminarFinal/ 5_jaya/Ausarbeitung.pdf

[2] Орлов С.А. Программная инженерия: технология разработки программного обеспечения, 5-е изд. «Питер», 2017, 634

[3] С. Макконнелл, Совершенный код. М: Русская редакция, 2005, $896 \mathrm{c}$.

[4] Полевщиков И.С. Особенности изучения способа тестирования базового пути студентами бакалавриата в рамках дисциплины
«Тестирование программного обеспечения» (часть 1) // Молодой ученый. 2015. №18. С. $10-12$

[5] Майерс Г. Искусство тестирования программ. Пер. с англ. под ред. Б.А. Позина. М.: Финансы и статистика, 1982, 176 с.

[6] Дженнифер Коул, Томас Горэм и др. Принципы тестирования программного обеспечения http://www.gcmsite.ru/?pg=art\&id=software-testing

\section{THE ANALYSIS OF TEST PRINCIPLES OF SOFTWARE}

Tamilla Bayramova ${ }^{1}$, Nazakat Malikova ${ }^{2}$

${ }^{1,2}$ Institute of Information Technology of ANAS, Baku, Azerbaijan,

'toma_b66@mail.ru, ${ }^{2}$ naranara_68@mail.ru

Abstract - Information about the terms used in the testing process of software, tools used for testing and different methods is given in the article. The primciples of testing are analyzed and the importance of considering them in the testing process is emphasized here.

Key words - software engineering; test principles; test-case; test plan; test design. 